\title{
Family Resilience: Prisoner's Perspective (A Phenomenology Study in Kedungpane Correctional Institution Semarang)
}

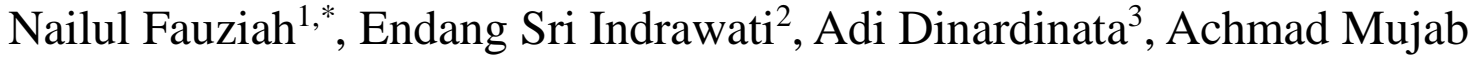 \\ Masykur $^{4}$ \\ ${ }^{1}$ Program Doktoral Fakultas Psikologi Universitas Airlangga, Jl. Airlangga 4-6, Surabaya \\ 1,2,3,4 Fakultas Psikologi Universitas Diponegoro, Jl. Prof. Soedarto, SH, Kampus Undip Tembalang, Semarang, \\ Indonesia 50275 \\ *corresponding author email: nailulburhan@gmail.com
}

\begin{abstract}
Incarceration is an experience that is torturous, severe, full of suffering, frightening, worrying and full of pressure for both the prisoner and the whole family. Good adaptability is needed to face the dynamic changes that are stressful and challenging so that they can recover quickly and can maintain their integrity and function as a family which is commonly referred to as family resilience. This research is a qualitative research which aimed to examine family resilience based on the phenomenological perspective of prisoners assisted by Kedungpane prison Semarang. The study involved 6 respondents from various backgrounds of crime cases with various length of incarceration. Data were collected using in-depth interviews with participants and analyzed using Data Explication method. The results show various resilience observed in the prisoners' families. There were two subjects who experienced major shocks in their domestic life and ended in divorce. Another subject, despite experiencing shocks, was still able to maintain and build up his family's resilience quite well. Strong family belief system in commitment, family patterns, communication, social support, positive perspective on reality, optimism, transcendence, spirituality and religiosity has a considerable effect on the strength of family resilience.
\end{abstract}

Keywords: Family resilience, Prisoner's Perspective, Phenomenology.

\section{INTRODUCTION}

Incarceration and correction for prisoners, as well as the loss of significant persons experienced by the families, spouses and children of the prisoners, is a life event that actually becomes a reality and serious psychosocial stressor. Only individuals who have good resilience are able to make this situation better. On the contrary, this condition might be an epiphany or the turning point for the better life.

A family with high resilience will not be split up. At the beginning, it may experience a little shock, but in the end, resilience will be able to guide this family to live a much better life. On the other hand, families that do not have high resilience will usually experience separation, even destruction when facing the fact that their family member is imprisoned. At the very least, there will be disturbances that damage the structure and dynamics in the family so that they no longer function normally and properly.
Family dynamics, particularly related to family resilience and the functioning of prisoners' families, invite researchers to go deeper into understanding and exploring the phenomena that is forgotten by our society. While, in fact they do exist, in numbers that cannot be negligible. For this reason, the researchers are determined to examine this phenomenon more deeply by using a qualitative approach.

\subsection{Literature Review}

The concept of family resilience is rooted in an understanding of individual resilience. Resilience is a process of adapting well in facing adversity, trauma, tragedy, threats, or even significant sources of stress. The concept of resilience includes not only the ability to survive but also to rise again from a crisis. In general, research on resilience focuses on individual resilience, with special attention to children who are in danger to experience adversity.

Walsh [1] stated that the term family resilience refers to the coping and adaptation abilities of the 
family as a functional unit from family breakdown to being a challenge. Resilience involves dynamic processes that help adapt to significant problems. These strengths and resources allow individuals and families to successfully face crises and persistent problems. In addition, the strengths and resources they have can recover and grow from unpleasant experiences. The concept of family resilience extends from observing individuals (family member) as a potential resource for individual resilience to observing the family as a functional unit in family resilience [2].

Kalil [3] suggested that the fundamental difference between individual resilience and family resilience lies in the roots and sources of the concept of resilience. Individual resilience is rooted in the perspective of the development of human life and focuses on how individuals become resilient in facing difficulties or challenges in life. Family resilience is rooted in a positive perspective and perceive the family as a collective unit of a number of individuals who interact and have their own strength.

The appearance of the term family resilience is built on theories and research on stress, coping, and family adaptation [2]. Previous researchers started a study of family stress with the assumption that 1) family members interact and support each other, 2) the presence of stressors requires families to be able to adapt and make adjustments, and 3) certain rules and communities will encourage coping and family adaptation [4].

McCubbin \& McCubbin, stated that family resilience is built by the success of families using coping during life transitions, stress or adversity [5]. Consistent with the strength and adaptability approach, McCubbin and McCubbin [6] define family resilience as the characteristics, dimensions and abilities of families in helping families to survive problems by finding change and adaptation in dealing with crisis situations. Family resilience is a pattern of positive behavior and the functioning of individual and family abilities that arise in situations under pressure or a circle of difficulties that weaken the family's ability to recover by maintaining integrity as a unit if necessary, to ensure and restore the wellbeing of family members and families as a whole unity [5].

McCubin [7] mentions two components of family resilience, namely a) the ability of the family to maintain a pattern of functioning that is developed after difficulties and stress; b) the family's ability to recover quickly from trauma or their events that caused changes in the family. The two components in family resilience are referred to as elastic and floating characteristics. A resilient family is a family that shows interaction as something dynamic, integration between protective and improvement factors which include optimism, spirituality, harmony, flexibility, communication, financial management, time and recreation, routines and rituals, and social support [8].

\section{METHOD}

This research is a phenomenological study using a qualitative approach that tries to deeply understand the subject's field of experience. The qualitative methodology used in the study was in-depth interviews with family members to explore family resilience aspects when a family member is imprisoned. The qualitative methodology allows researchers to hear the participants' own perspective [9]. The particular approach was chosen to identify the meaning of life experience. Qualitative approaches can be described as interpretive approaches, artistic approaches, systematic approaches and theory-driven approaches. Phenomenology research has included experience that has meaning for mind [10]. IPA (Interpretative Phenomenology Analysis) has focused to explore how participant provide their experience in their personal and social world. IPA tries to understand "what it feels like" from participant perceptions to dig up their perspective [11].

Subjects who were involved in this research were prisoners who have undergone incarcerations in Kedungpane Prison for at least 1 year. After going through discussions with the key person assisting officers at the Correctional Institution, 6 subjects were selected.

Data for the study were obtained through indepth interviews with structured interview guides using semi-open questions. These data were then analyzed using a data explication analysis model. Explication is the process of making the respondent's expression explicit which is implicit or implied (Subandi, 2010) [12]. 
Table 1. Participant's Demographic

\begin{tabular}{|c|c|c|c|}
\hline No & Initial & Term of imprisonment & Age \\
\hline 1 & $\mathrm{Sg}$ & 17 & 40 tahun \\
\hline 2 & $\mathrm{An}$ & 14 & 44 tahun \\
\hline 3 & $\mathrm{Ct}$ & 12 & 36 tahun \\
\hline 4 & $\mathrm{Bw}$ & 12 & 47 tahun \\
\hline 5 & $\mathrm{Fz}$ & 12 & 50 tahun \\
\hline 6 & $\mathrm{Rn}$ & 12 & 26 tahun \\
\hline
\end{tabular}

\section{RESULTS}

The results of the study were presented in three episodes with different themes to facilitate the analysis process and to understand more in-depth cases, namely: pre-prison episodes, initial episodes in prison and episodes of staying in prison. Three themes in the pre-prison episode are: participants' background (work) and initial family conditions. Five themes in the initial prison episode are psychological conditions, family response, family changes, adaptation, and social support. And four themes in the persistent episode in the prison, namely daily activities, interpreting imprisonment, increasing religiosity, family interpreting. There were a total of 10 themes observed from the analysis.

In the Pre-Prison Episode,

Several themes were found, namely:

a. Case Background

The subject $\mathrm{Sg}$ is a civil servant in a district who is involved in a bribery case at his agency. The subject was convicted under the Corruption Crime Article with a 4-year imprisonment. The subject $\mathrm{Ct}$ was accused of being a drug dealer because the warehouse where the items were being kept by the subject turned out to be a container of a lot of drugs that were put in the generator engine. Subject $\mathrm{Bw}$ is a father of 3 children. The subject was a salesperson who was charged with sexual crimes against a minor. Fz is an ex member of People's Representative Council (DPR) who is also a property entrepreneur in a city in Central Java who has stumbled over a fraud problem. Meanwhile, $\mathrm{Rn}$ stumbled on a rape case that made him sentenced for 3.5 years.

\section{Initial Episode in Prison}

a. Psychological Conditions

All subjects admitted that going to prison was a scary, uncomfortable, even sad situation. Subjects also reported stress and depression due to sudden changes as a result of their incarceration. b. Family Response

The response of the family in each case the subject is different. But in general, the family felt shock, sad, and stressed, because family members are confronted by the law. Luckily, because the family understood the conditions that the research subjects had to experience. Different responses were observed from the families of the subjects An and Rn who had problems before they went to prison.

c. Family Change

The biggest change experienced by the subject's family apart from the loss of relationships and togetherness was the financial factor. The whole subject is a breadwinner for his family.

d. Adaptability

Adaptability is an important factor for the continuity of subjects in prison. At first, all the subjects felt a downturn in prison. But gradually, they are forced to adapt to the situation and be realistic in seeing the life and future they have to live in.

e. Social Support

Social support is necessary for the subject in dealing with the cases and the imprisonment he has to face. Family, in this case is spouse and children, as well as extended family (parents and relatives), and the environment is a strong source of support for the assisted members.

\section{Episode of Settling in Prison}

a. Daily Activity

The daily activities that the inmates undergo while serving their sentences are monotonous and boring. Getting up in the morning, taking a shower, eating, and chatting with fellow residents are routine activities that they have to do until they finally go back to sleep. To get rid of boredom and maintain fitness, the assisted residents usually also do sports, volley balls, chess, line of march

b. The Meaning of Incarceration 
The subject $\mathrm{Sg}$ interpreted his imprisonment with gratitude. In line with $\mathrm{Sg}$, An even admitted that prison is a "gift" that allows him to change, from pursuing the life of the world to immediately undergo repentance because of his crimes and wrong steps. The subject of $\mathrm{Fz}$, interpreted prison as a reminder to be more careful and vigilant in his work. Meanwhile, the subject of $\mathrm{Rn}$, feels that prison makes him feel he must stop all the crimes he has committed. Likewise, the subject of $\mathrm{Bw}$, feels that prison is a place of redeem for his sins and mistakes. Meanwhile, the subject of $\mathrm{Ct}$, realized that there were many things that could be learned while in prison.

c. Increased Religiosity

An interesting phenomenon that is commonly encountered in prisons is the mass repentance observed in the inmates.

d. Family Meaning

Some of the subjects consider the family was a very large source of support. Family is also a source of happiness, the reason they must survive and improve.

\section{DISCUSSION}

The findings on 4 research subjects, $\mathrm{Sg}, \mathrm{Fz}, \mathrm{Bw}$ and $\mathrm{Ct}$, show that the subject and his family have similarities in understanding the reality. Subjects perceive that the imprisonment they have to face is a process that enables them to become more positive, better and more efficient when they return to their family and society. Subjects and families seem to realize that this difficult situation must be handled by supporting and trusting each other.

This is in accordance with the results of research by Larson [13]. In prison imported expectations interact with responses to coercive situational forces, since prisons use coercive power to bring inmates into compliance with institutional rules. Etzioni correlated inmates' perceptions of powerlessness with the increasing imposition of coercive power, and found that some inmates accept this situation and expect to exert only reduced control, balancing opportunities with expectancies, though adaptive strategies vary. They build friendship, solidarity, loyalty to create relation in prison [14].

They adapt by withdrawing from inmate society and cutting social bonds and contacts with the outside world; and they attempt to construct a life within the prison. Other inmates may develop primary relationships and respond to prison conditions in solidarity with others, while those perceiving opportunities (although limited) to control their environment, may feel efficacious.
Christian [15] shows that much of the familycentered work highlights the potential benefits for the prisoner of maintaining ties to family during the incarceration period, and particularly after release. Prisoners' families are essentially placed in a double bind as they choose whether to maintain the prisoner, or to devote resources to the family's life in the community. Families who successfully maintain relationships with prisoners often recognize this precarious situation and set clear boundaries with the prisoner that enable them to maintain a connection without compromising the family's well-being.

Increased religiosity is very visible in all subjects, becoming more enthusiastic in carrying out religious orders, following studies, reading holy books, and being more diligent and solemn in worship. Changes in the orientation of life can also be seen in all subjects, where the subject undergoes repentance and is determined to live a more religious life and is increasingly resigned to approaching God.

While Subject An and Rn, although they also had a positive perspective on the imprisonment they experienced, repented and became more religious, but there was no visible support and support from their families, especially their spouses, to be able to proceed better. Both of An's wives have even filed for divorce. As for the Rn case, his family could not be saved because there were no more commitments caused by a weak and complicated family foundation.

Ryon [16] suggested a family-based intervention program to help detainees improve their wellbeing. The underlying factors present in a child's history and environment, including familial relations, unresolved trauma and unmet basic needs are all elements of the underlying ecology impacting the child's emotional and behavioral well-being. Interventions that address family functioning within this ecological context demonstrate positive outcomes among anti-social and delinquent youth [17].

Looking at the Organizational Patterns in the subject family, imprisonment results in a change in patterns that require good adaptability from all family members, especially in relation to social and economic resources. Physically, they are separated, but inwardly, the responsibility and commitment, the subject and his family are still united. Sg has a wife who is a civil servant who is also economically productive. $\mathrm{Ct}$ is an elementary school teacher who is also economically independent. $\mathrm{Fz}$ has several companies that are also managed by his wife. Meanwhile, $\mathrm{Bw}$, since he was imprisoned, the family pattern immediately changed because his wife and children became more independent through entrepreneurship. The interesting thing was admitted by the subjects of $\mathrm{Sg}$ and $\mathrm{Bw}$, who admitted that they were still productive making money while in prison by helping out and becoming instructors at prison. 
Meanwhile, from the communication process, there are significant changes because the subject and his family are separated physically. The subject and his family can only meet on the day of the visit. The subject and his family always try to meet during the visit. During the visit, they not only let go of their homesickness, but were able to give attention to each other, communicate, discuss problems they were having and talk about their life plans. One thing that really helps the possibility to communicate with the family by using cellphones and telephones from the prison.

Christian [15] suggested a finding about the extent of prisoner contact with families was scant, with data suggesting 57 percent of incarcerated fathers never had a personal visit with their children since their admission to prison, and that 62 percent had some type of contact including by phone, mail, or a visit [18]. Christian [19] found that families might maintain contact with a prisoner because they feel responsible for monitoring the system's treatment of the individual, or wish to provide moral support for the prisoner. Maintaining the connection requires families to navigate the prison bureaucracy and develop a number of coping strategies [20]; [19]; [21].

Studies indicated that incarceration disrupts the family structure, as the imprisonment creates an emotionally unstable environment [22]. During the incarceration period, the family "doing time on the outside" [20], reorganizes itself, and in some instances the newly single parent is forced to undertake multiple roles and responsibilities, particularly if the incarcerated parent contributed to the household [23]. These immediate and long-term consequences may have implications for the family's desire and ability to stay connected to the incarcerated individual.

One indicator of the difficulties faced by families is Holt and Miller's [24] finding that "contact from legally married wives of first term inmates grew fewer through the second year, suggesting that the marital relationship deteriorates as the years in prison pass." This change in the frequency of contact may reflect the difficulties families encounter as they maintain relationships, and it may also point to the lack of reciprocity in the prisoner family relationship.

In addition to the tradeoff's families make while the prisoner is incarcerated, they also may find that the payoff during the post-incarceration period is not what they expected. Wolff and Draine [25] pointed out that women find the prisoners' reentry to the family to be stressful and sometimes disappointing. Families may be surprised at the support and assistance the former prisoner requires.

\section{CONCLUSION}

Based on the results of data analysis, it can be concluded that the resilience of the families of prisoners who were study participants tended to vary. There were two subjects who experienced major shocks in their domestic life and ended in divorce and family destruction. Another subject, despite experiencing shocks, was still able to maintain and build his family resilience quite well. Strong family belief system which consists of of commitment, family patterns, communication, social support, a positive perspective on reality, optimism, transcendence, spirituality and religiosity remains to be the factors that have a considerable influence on the strength of the subject's family resilience, in addition to the term of imprisonment that is received by the subject.

\section{AUTHORS' CONTRIBUTIONS}

The all author confirms responsibility for the following: study conception and design, data collection, analysis and interpretation of results, and manuscript preparation.

\section{ACKNOWLEDGMENTS}

This research was supported by Faculty of Psychology, Universitas Diponegoro, Semarang, Indonesia.

\section{REFERENCES}

[1] F. Walsh, Strengthening Family Resilience. Strengthening Family Resilience. $2^{\text {nd }}$ ed, vol. 38, New York: The Guilford Press, 2006. DOI: https://doi.org/10.1086/514469

[2] F. Walsh, Strengthening Family Resilience. Adolescence, vol 38, 2003b. DOI: https://doi.org/10.1086/514469

[2] F. Walsh, Family Resilience: A Framework for Clinical Practice. Family Process, 42(1), 2003a

[3] A. Kalil,, Family resilience and good child outcomes. A review of the literature. Wellington: Centre for social research and evaluation, ministry of social development, Te manatu Whakahiato Ora, 2003.

[4] W. C. Nichols, Roads to understanding family resilience: 1920 s to the twenty-first century. In 
In D.S. Becvar (ed). Handbook of family resilience. New York: Springer Science. Business Media, 2013.

[5] H. I. McCubbin, M. A. McCubbin, Family Assessment: Resiliency, Coping, Adaptation: Inventory for Research and Practice. Madison,WI: University of Winconsin, 1996.

[6] H. I. Mccubbin, M. A. Mccubbin, Typologies of Resilient Families: Emerging Roles of Social Class and Ethnicity. Family Relations, 37(3), 1998, pp. 247-254. DOI: https://doi.org/10.1086/639018

[7] H. I. McCubbin, A. N. McCubbin, I. A. Thompson, Y-S. Han, T. C Allen, Families Under Stress: What makes them resilient. Journal of Family and Consumer Sciences, 89(3), (1997), 2.

[8] J. M. Patterson, Understanding family resilience. Journal of clinical Psychology, 58(3), 2002, pp. 233-246.

[9] J. W. Creswell, Penelitian kualitatif dan desain riset: Memilih di antara lima pendekatan 3nd ed. Yogyakarta: Pustaka Pelajar. 2015.

[10] J. A. Smith, (eds.), Psikologi kualitatif: panduan praktis metode riset. Terjemahan dari qualitative psychology a practical guide to research method, Yogyakarta: Pustaka Pelajar. 2009.

[11] J. A. Smith, M. Osborn, Interpretative Phenomenological Analysis. In J. A. Smith (Eds.), Qualitative Psychology: Practical Guide to Research Methods, London: SAGE Publications. 2007.

[12] M. A, Subandi, Psikologi Dzikir, Studi Fenomenologi Pengalaman Transformasi Religius, Yogyakarta: Pustaka Pelajar, 2009.

[13] J. H. Larson, 1984). Women, friendship, and adaptation to prison. Journal of Criminal Jusrice, Vol. 12, 1984, pp. 6001-615.

[14] L. D. McCubbin, H. I. McCubbin, (2013). Resilience in Ethnic Family System: A Relational Theory for Research and Practice. In D. Becvar (Eds.), Handbook of Family Resilience, Newyork: Springer, 2013, pp. 175195.

[15] J. Christian, J. Mellow, S. Thomas, (2006). Social and economic implications of family connections to prisoners. Journal of Criminal Justice, 34(4), (2006), 443-452. DOI: https://doi.org/10.1016/j.jcrimjus.2006.05.010.
[16] S. B Ryon, K. E. Winokur, A. E. Kosloski, Community-based and family-focused alternatives to incarceration: A quasiexperimental evaluation of interventions for delinquent youth, Journal of Criminal Justice, 51 (May), 2017, 59-66. DOI: https://doi.org/10.1016/j.jcrimjus.2017.06.002.

[17] S. Gorman, P. Tolan, Henry, Developmental psychological model of the relation of family functioning to pattern of delincquency. Journal of Quantitative Criminology, 16(2), (2000).168198.

[18] C. J. Mumola, Incarcerated parents and their children (Bureau of Justice Statistics Special Rep.). Washington, DC: Bureau of Justice Statistics. 2000.

[19] J. Christian, Riding the bus: Barriers to prison visitation and family management strategies. Journal of Contemporary Criminal Justice, 21(1), (2005), pp. 31-48.

[20] D. Brahman, J. Wood, From one generation to the next: How criminal sanctions are reshaping life in urban America. In J. Travis \& M. Waul (Eds.), Prisoners once removed: The impact of incarceration and reentry on children, families, and communities, Washington, DC: Urban Institute Press. 2003, pp. 157-188.

[21] M. Comfort, In the tube at San Quentin: The 'secondary prisonization' of women visiting inmates. Journal of Contemporary Ethnography, 32(1), (2003), pp. 77-107

[22] L. E. Wright, C. B. Seymour, Working with children and families separated by incarceration: A handbook for child welfare agencies, Washington, DC: CWLA Press, 2000.

[23] C. Shapiro, N. Schwartz, Coming home: Building on family connections. Correction Management Quarterly, 5(3), (2001), 52-61

[24] N. Holt, D. Miller, Explorations in inmatesfamily relationships, Sacramento: California Department of Corrections, 1997.

[25] N. Wolff, J. Draine, Dynamics of social capital of prisoners and community reentry: Ties that bind? Papers presented at a conference organized by the Public Health Dimensions of Reentry: Urban Institute Reentry Roundtable, Los Angeles, 2002 December. 